\title{
Alvar SOESOO*
}

\section{ON THE PETROCHEMISTRY OF PRECAMBRIAN QUARTZ-FELDSPAR GNEISSES (LEPTITES) OF ESTONIA AND SUURSAARI (GOGLAND), RSSFR}

Petrochemical composition of quartz-feldspar (Q-Fsp) gneisses from 24 drill cores of the South-Estonian, West-Estonian, and Tallinn areas, and from nine outcrops on Suursaari, RSSFR, (53 samples in all) have been analysed. Q-Fsp gneisses of the Estonian basement and Suursaari are fine grained, grayish-red rocks. Principal minerals are quartz, plagioclase, potash feldspar, and biotite; the additional minerals are hornblende, muscovite, epidote, apatite, ore minerals, garnet, and orthite. Q-Fsp gneisses of Suursaari differ from those of the other areas in their higher content of quartz and plagioclase and lower content of potash feldspar and biotite. Differences can be also observed between the chemical composition of the rocks of different areas. The quartzfeldspar gneisses of the Tallinn area and Suursaari have comparatively higher contents of silica oxide and lower contents of aluminium, magnesium, and calcium oxides. High content of potash is characteristic of all Estonian Q-Fsp gneisses. Variation diagrams based on the Niggli main value show similarity of $a l, f m, c$ and alk dynamics of the Tallinn and West-Estonian areas. The plots of the samples corresponding to these two areas also overlap on Neelov's diagram $(a-b)$.

To classify the Q-Fsp gneisses of the Tallinn area according to their chemical composition, cluster analysis has been used. The best clustering results were obtained using Niggli values as input data: two main groups were distinguished and one of them fell into three subgroups.

Comparing the chemical composition of the Q-Fsp gneisses of Estonia and Suursaari with their analogues from Finland, the similarity of the rocks of Pellinki and Kiuruvesi areas to the Q-Fsp gneisses of Suursaari and partly also to the gneisses of the Tallinn area can be observed.

\section{Introduction}

Quartz-feldspar gneisses (leptites) are metamorphic rocks generally associated with iron-rich, primarily volcanic-sedimentary formations. Their parental rock identifications would contribute to the study of the development of geological structures.

Several hypotheses on the origin of leptites have been introduced. In the studies of the Q-Fsp gneisses of the Ukrainian and Baltic shields, they have been characterized as granite-aplites, different products of granitization, metamorphic rocks and their tuffites, etc. (Щербак et al., 1978; Никольский, Наумов, 1977; Скобелев, 1987; Marttila, 1976). Chernov (Чернов, 1964) describes leptite gneisses of the Karelian Bolshoye Ozero area as metamorphic rocks of acid tuffaceous and tuffite schists. Q-Fsp gneisses of Pellinki area have been considered to be schists and gneisses formed on the basis of arkoses and graywackes (Laitala, 1973). Presumably the Q-Fsp schists of the Ylivieska-Himanka area have been also formed on the basis of arkoses and graywacke (Salli, 1964). Leptites (acid tuffaceous and tuffite schists) of the Kiuruvesi area are associated with volcanic amphibolites and agglomerates (Marttila, 1976).

* Eesti Teaduste Akadeemia Geoloogia Instituut (Institute of Geology, Estonian Academy of Sciences). 200105 Tallinn, Estonia pst. 7. Estonia. 
The rocks of the Estonian basement associated with Q-Fsp gneisses have several similarities with those of the above-mentioned areas: Q-Fsp gneisses and schists are often surrounded by mica gneisses and amphibolites; intercalations of mica gneisses and amphibolites are quite usual. Leaving open the identification problems of the primary rock, this paper focuses on a comparative petrochemical study of Q-Fsp gneisses of Suursari and three areas in Estonia.

\section{Materials and methods}

Altogether 53 samples from 24 drill cores of Estonia and 9 outcrops of Suursaari (Gogland), Russian SSFR, have been studied. Considering the structure of the crystalline basement of the Baltic region (Геологическая карта ..., 1980), the samples were grouped according to the four areas: Suursaari, South Estonia, West Estonia, and Tallinn area (Fig. 1).

Quartz-feldspar gneisses (leptites) of the Estonian basement are leucocratic, of granitic composition, gray or pinkish-gray and homogenous fine-grained rocks. In drill cores of the basement they are described as separate layers, usually with clear-cut contacts with associating rocks. Macroscopically schistose texture can be traced, especially in the SouthEstonian area; the massive texture of the Tallinn area has been also described (Кристаллический фундамент ..., 1983). Every sample taken from a drill core is a random unit; its parameters have a probabilistic nature that can be described in a four-dimensional space (i. e. three space coordinates + time). The results of analyses of every single sample must be taken with precaution. For more reliable information we must proceed from a set of samples organized according to a certain parameter, not from a single sample.

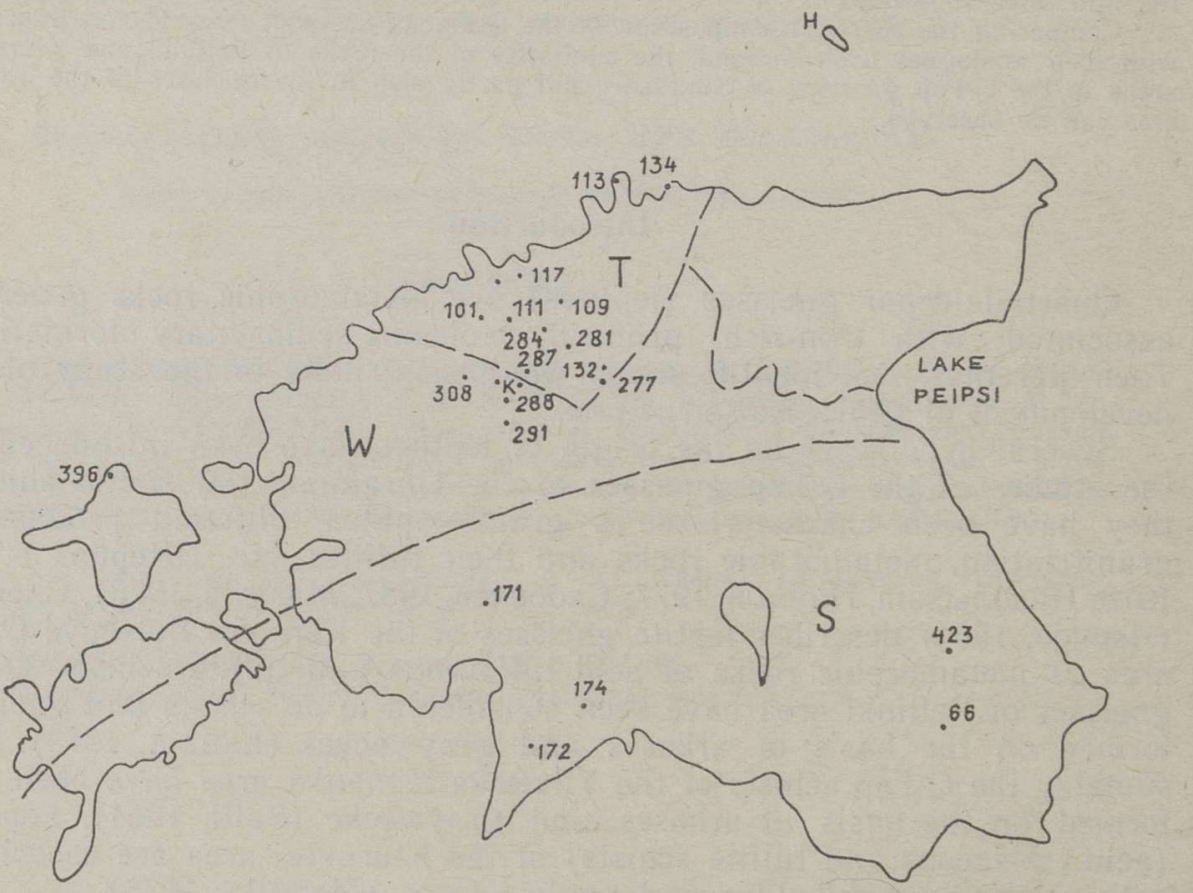

Fig. 1. Location of the studied drill holes through the Estonian basement. The dashed lines indicate the boundaries between the structural areas: S - South Estonia, W West Estonia, T - Tallinn area, and H - Suursaari (Gogland). 
From petrological point of view it is suitable to group rock samples according to the characteristic si. By ordering the analyses according to the value of $s i$ and then plotting the graphs of Niggli main values against the $s i$-axis, we get a kind of variation diagram where every sample is displayed as a point (Fig. 2). The sample sets corresponding to the chosen structural units (e.g. areas or drill cores) can be generalized by regression lines smoothing the random deviations in petrochemical characteristics. The angle of elevation of a regression line reflects the dynamics of petrogenic components or their groups.

The shape of the variation diagram and variation range of the $s i$ value indicate the character of the primary rock of Q-Fsp gneisses and local or regional processes during or after metamorphism.

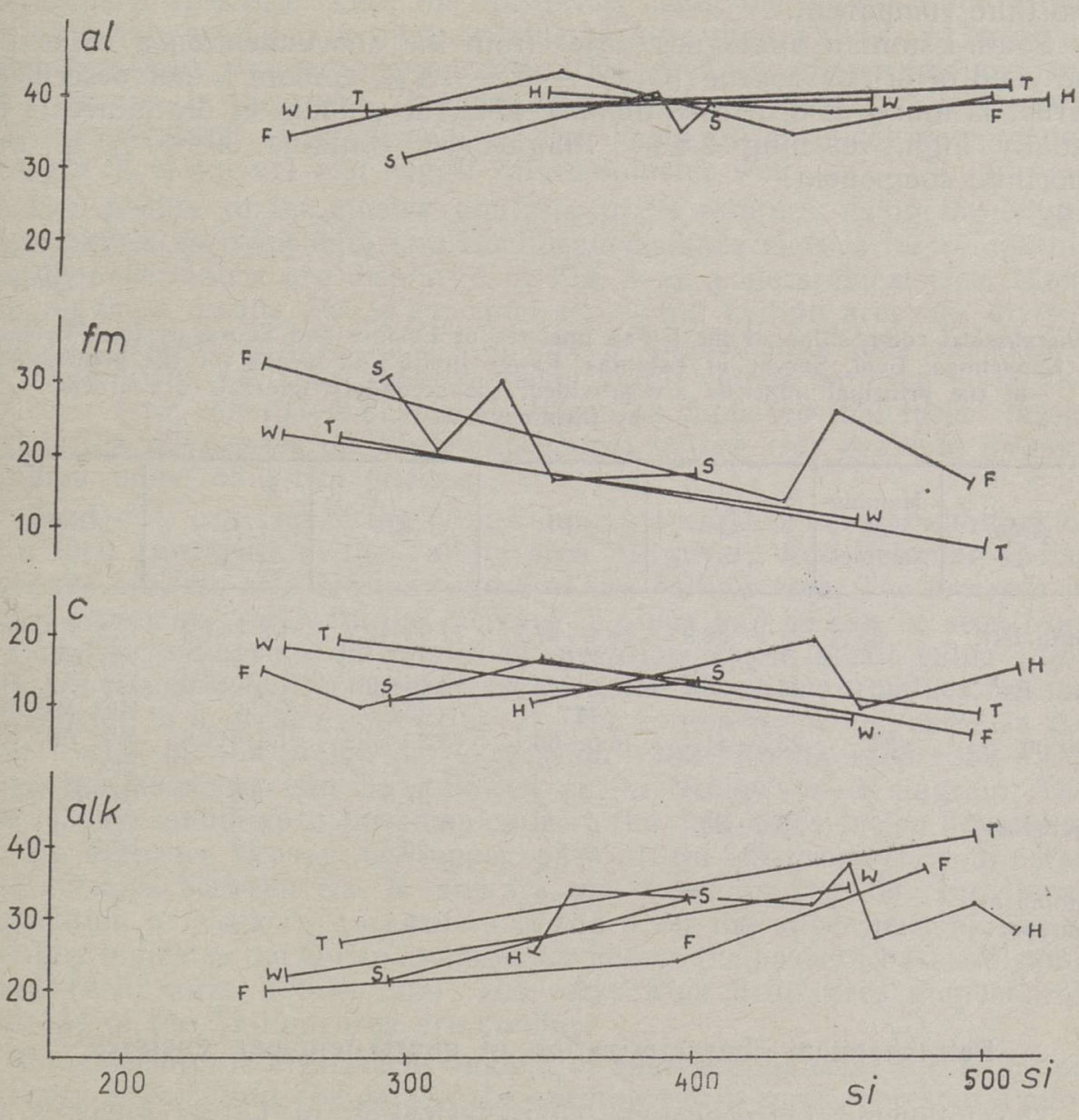

Fig. 2. Variation diagram of quartz-feldspar gneisses of Estonia and Suursaari based on Niggli main values. The four studied areas are characterized by the regression lines smoothing the random deviations of single samples: S - South Estonia, W - West Estonia, T - Tallinn area, H - Suursaari. For comparison, data on Pellinki, Ylivieska, and Kiuruvesi areas, Finland (F), are also provided (cf. Laitala, 1973; Salli, 1964; Marttila, 1976). 


\section{Mineralogical composition}

Data on the mineralogical composition of the Q-Fsp gneisses of Estonia and Suursaari are given in Table 1.

The mineralogical composition of the rocks in the thin section has been determined by $M$. Niin and H. Koppelmaa, the Geological Survey of Estonia.

Rocks of the Tallinn area often contain muscovite (Ms; 12 samples, mean $1.2 \%$ ), epidote (Ep; 5, 0.4\%), and apatite (Ap; 9, 0.15\%). The gneisses from the drill cores number 111 and 114 contain $0.5 \%$ of garnet (Gr). The rock samples from Suursaari do not contain apatite; epidote occurs in abundance, varying from $0.1-7.3 \%$; the content of ore minerals (Erz) is up to $2.5 \%$.

The Q-Fsp gneisses of West Estonia do not contain epidote, but they often yield apatite $(0.1-0.2 \%)$; two samples from Kohila drill core contain hornblende (Hbl) as well as orthite (Orth). Plagioclase of the Q-Fsp gneisses of the West-Estonian and Tallinn areas contain $19-40 \%$ of the anorthite component.

South-Estonian analogues differ from the above-mentioned rocks by the yield of orthopyroxene (Orx) - 0.2-1.4\%; epidote is not described, garnet is found in drill core number 174. The amount of ore minerals is usually high, reaching $2.5 \%$. Plagioclase contains $30-37 \%$ of the anorthite component.

Table 1

Mineralogical composition of the Q-Fsp gneisses of Estonia and Suursaari (by M. Niin, H. Koppelmaa, Geol. Survey of Estonia). Range limits and means for the percentages of the principal minerals are provided; the secondary minerals are orded by their content

\begin{tabular}{|c|c|c|c|c|c|c|}
\hline Area & $\begin{array}{l}\text { Number } \\
\text { of } \\
\text { samples }\end{array}$ & Q & $\mathrm{Pl}$ & $\mathrm{Kfs}$ & $\mathrm{Bt}$ & Others \\
\hline South Est. & 8 & $22.1-38.9$ & $\begin{array}{c}18.4-57.7 \\
32.6\end{array}$ & $\begin{array}{c}11.9-42.7 \\
32.9\end{array}$ & $\frac{1.8-i 1.9}{4.3}$ & Erz, Ap, Orx \\
\hline West Est. & 10 & $\begin{array}{c}16.8-30.4 \\
23.2\end{array}$ & $\begin{array}{c}10.2-49.9 \\
34.7\end{array}$ & $\begin{array}{c}20.6-42.1 \\
33.5\end{array}$ & $1.5-15.0$ & $\begin{array}{l}\text { Erz, Ap, Ti } \\
\text { Hbl, Ms, Ort }\end{array}$ \\
\hline Tallinn & 24 & $23.3-41.4$ & $16.5-60.1$ & $15.2-53.9$ & $1.3-11.8$ & $\begin{array}{l}\text { Ms, Ap, Ep, } \\
\text { Erz }\end{array}$ \\
\hline Suursaari & 9 & $\begin{array}{c}18.6-55 \\
39.2\end{array}$ & $\begin{array}{c}17.5-46.6 \\
36.6\end{array}$ & $\begin{array}{l}27.5 \\
8.7-36.3 \\
20.5\end{array}$ & $\begin{array}{l}5.6 \\
0.1-10.4\end{array}$ & $\begin{array}{l}\text { Gr, Ti, } \mathrm{Hbl} \\
\text { Erz, Ep, Ti } \\
\text { Hbl }\end{array}$ \\
\hline $\begin{array}{l}\text { Estonia and } \\
\text { Suursaari }\end{array}$ & 51 & 31 & 34.2 & 28.6 & 4.9 & \\
\hline
\end{tabular}

\section{Petrochemical characterization of quartz-feldspar gneisses}

The following petrochemical characterization of Q-Fsp gneisses is based on the analyses of Niggli main values and parameters of petrochemical net by Neelov (Четвериков, 1956; Неелов, 1980; Ефремова, Стафеев, 1985). The Q-Fsp gneisses of the Tallinn area are enriched with potash. Correlation between the increase in $\mathrm{K}$ content and si can be followed. The ratio of $a l$ and alk values is usually negative. The method of Niggli values enables to distinguish two petrochemically homogenous groups of drill cores: numbers $132,134,281$ and $111,114,287$. On the 
variation diagram (Fig. 2), these groups would occupy the left and right parts of line $\mathrm{T}$, respectively. The samples of the first group have typically high contents of aluminium, iron, and calcium oxides (Tables 2 and 3 ). Several petrochemical indices suggest that the rocks of this group might be products of metamorphism of basic volcanites and their tuffes.

On the Neelov $a-b$ diagram (Fig. 3) we can see the change of the direction of $a$ and $b$ : high values of $a$ and $b$ correspond to Q-Fsp gneisses of drill cores number 132 and 134 grouping with the analogous rocks from drill cores Kohila and number 308 of the West-Estonian area. The decrease in the parameters $a$ and $b$ occurs on a comparatively narrow petrochemical field. A relatively high number of samples from the Tallinn area (24) enabled to estimate the differences in petrochemical characteristics within the area using cluster analysis. From several sets of variables used as input data, the best results of clustering were obtained using the chemical composition data, and especially the Niggli main values, while the data of mineralogical composition (4 variables) did not yield a hierarchical structure. Also, the clustering using the Niggli main values as input data seems to be more reliable because these values are based on petrochemically comparable characteristics, such as atomic amounts and their groups in the rocks. It must be pointed out that for leucocratic rocks the classes distinguished on the basis of chemical composition (weight $\%$ of oxides) and Niggli values coincide well.

The results of the cluster analysis of 24 samples using the Niggli main values as input data and Euclidean distance metrics for computing the distance matrix are displayed in Fig. 4 as a hierarchical tree. Interpreting these results, the Q-Fsp gneisses of the Tallinn area are divided into two classes (I, II). Class I in turn is divided into three subclasses: $\mathrm{I} a, \mathrm{I} b$, Ic (Fig. 4). Subsequently, mean Niggli values for each class and subclass were calculated (Table 4). It can be supposed that these classes reflect the differences of the petrochemical nature (for example thermodynamic ones) of Q-Fsp gneisses.

The Q-Fsp gneisses of the West-Estonian area have several similarities with their analogues of the Tallinn area. However, West-Estonian Q-Fsp gneisses are less alkaline than those of the Tallinn area. The increase in alkali correlates well with the increase in silica and as can be seen from the variation diagram the angles of elevation of the alkali value $(a l k)$ line are almost equal for both areas. Also, the Niggli main values $f m$ and al coincide to a great extent (Fig. 2). The content of $\mathrm{Si}$ increases in the drill cores in the following succession: $308 \rightarrow$ Kohila $\rightarrow 288 \rightarrow 289 \rightarrow 291$. A similar sequence can be followed on the Neelov's $a-b$ diagram. The points corresponding to the samples from the drill cores in the beginning of the sequence occupy the upper part of the diagram (Fig. 3). The relationships between $\mathrm{Na}, \mathrm{K}$, and $\mathrm{Ca}$ are shown in Fig. $5 a$. The linear correlation of Neelov's parameters $a$ and $b$ on the upper part of Fig. 3 possibly indicates the Q-Fsp gneisses formed on the basis of basic volcanic rocks (drill cores Kohila, 308). The rocks from drill cores number 132 and 134 of the Tallinn area are similar.

Considering the insufficient amount of analysed material and a limited territory of sampling, the data of the examined drill cores represent a pilot study rather than an extensive investigation of the area, nevertheless they give some valuable information for correlating the West-Estonian Q-Fsp gneisses with those of the Tallinn area.

The South-Estonian area cannot be directly compared with the other study areas because Q-Fsp gneisses are not widely distributed here and the sampled localities are somewhat scattered. Comparatively higher contents of $\mathrm{Ti}, \mathrm{Mg}$, and $\mathrm{Fe}$ are characteristic of the rocks of this area (Tables 2 and 3 ). Similarly to Q-Fsp gneisses of Suursaari, Niggli main 


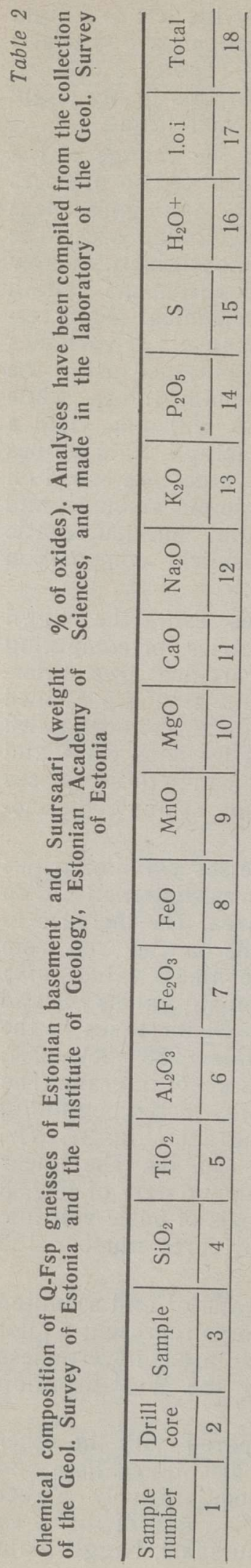

นี ชิ

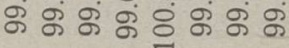

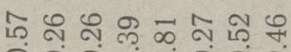
०ू० 000000

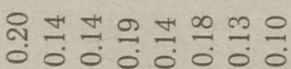

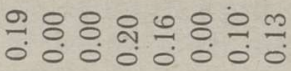
응 $\frac{\infty}{0}$ 융

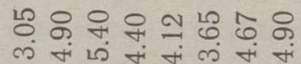
옹ํㄴ유운

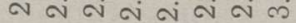

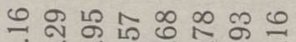
स สั

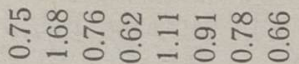

¿.8.

ํํ เิ้ - a

๙ ำ

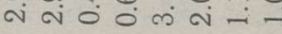

म

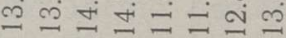

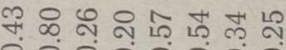
ชี

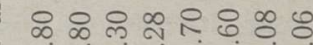

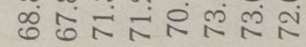

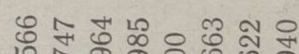

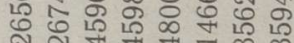

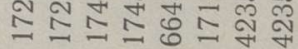

กำง

-
"시유 ลึ

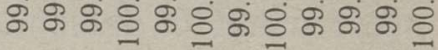

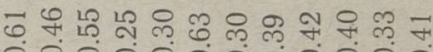

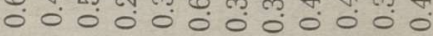

ㅇํㅇำ

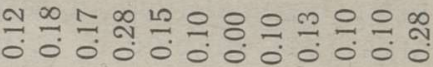

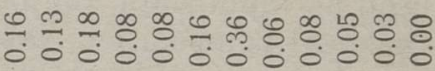

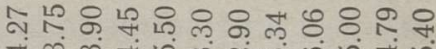
स ल

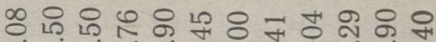

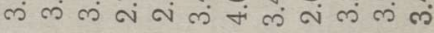

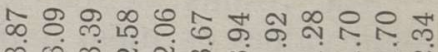

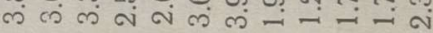

ฟิ นึ้

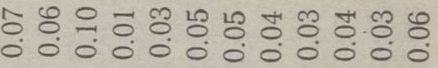

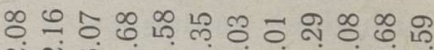
a a ल

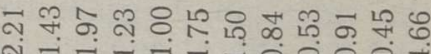

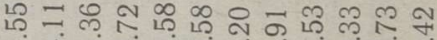

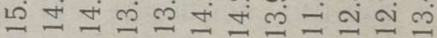

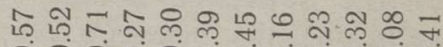
ฮั 000000000000 ส 8 ํํ유 ㄱำ ภำ 离

ำกน以น फ

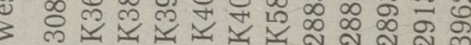

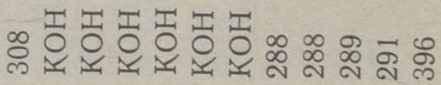

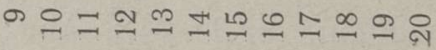


ஸิ காக்

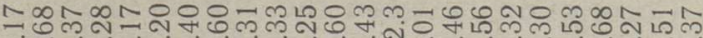

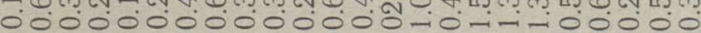

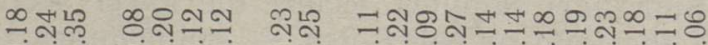

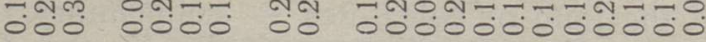

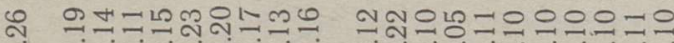 0 000000000 00000000000}

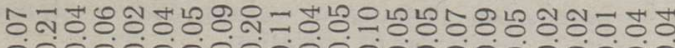
00000000000000000000000

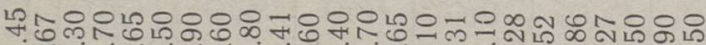

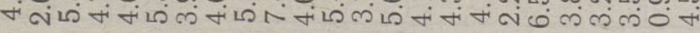

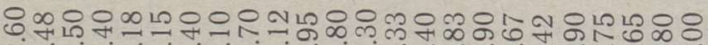

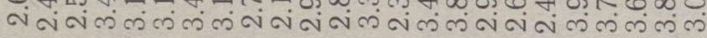

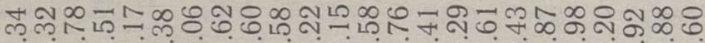

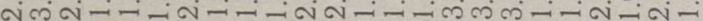

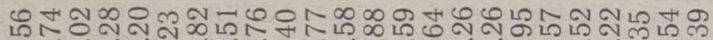
tio-io0000000000-1000-000

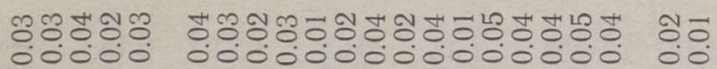

ำด

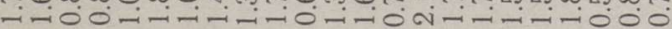

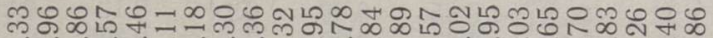
m000000000000-1-1-10-10-100

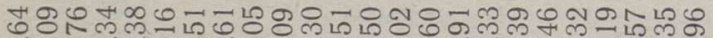

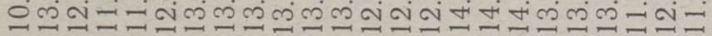

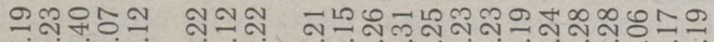
0000000000000000000000

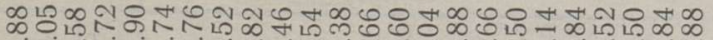

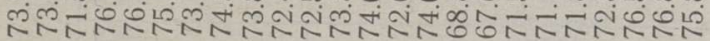
ฐ

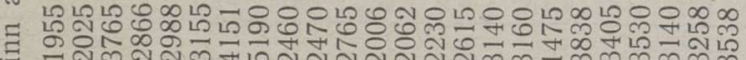

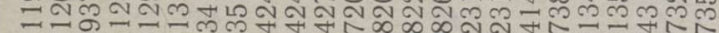

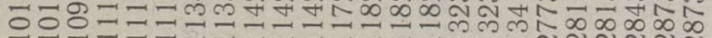

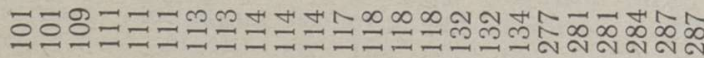

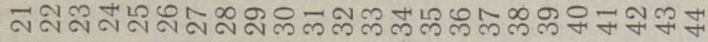

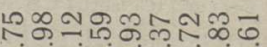
க்க்ட்க் க்

สํำㅇํㅇำ 000000000

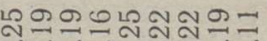
000000000

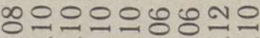
000000000

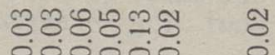

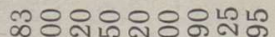
onm-iniman

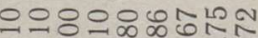

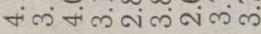

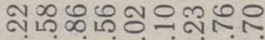
a-i-iain-i-

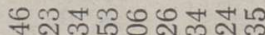
O०-iotio.

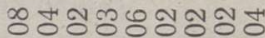
0.000 .000

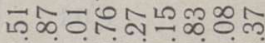
a-ion-io-in

ल -100 0 i० -

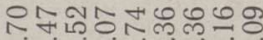
○ニさニヘニニニ

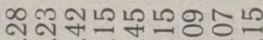
000000000 ๓

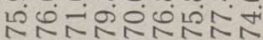

0,0 永 $7 m^{1}$ - เ่าง

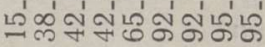

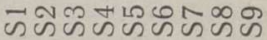

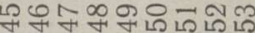


value $c$ increases proportionally to the increase in the value $s i$, while the correlation between $f m$ and $s i$ is absent (Fig. 2).

Q-Fsp gneisses of Suursaari are characterized by a low content of titanium oxide (analogously to the Tallinn area) and magnesium, calcium, and potassium oxides. Correlation between the Niggli values and the $\mathrm{Si}$ content is insignificant. Certain petrochemical data show similarity to the Si-rich analogues of the Tallinn area. On Neelov's diagram the points corresponding to the Suursaari samples occupy the lower section of the field (i. e. boundary of the field of volcanites + sedimentary rocks, and sedimentary rocks; Fig. 3). The distribution of $\mathrm{Na}, \mathrm{K}$, and $\mathrm{Ca}$ in the

Table 3

Statistical values of the chemical composition of the Q-Fsp gneisses, Estonia and Suursaari. Avg - average, Var - population variance of values, Std - standard deviation, cua - coefficent of variation

\begin{tabular}{l|c|c|c|c|c|c|c|c|c|c}
\hline Index & $\mathrm{SiO}_{2}$ & $\mathrm{TiO}_{2}$ & $\mathrm{Al}_{2} \mathrm{O}_{3}$ & $\mathrm{Fe}_{2} \mathrm{O}_{3}$ & $\mathrm{FeO}$ & $\mathrm{MnO}$ & $\mathrm{MgO}$ & $\mathrm{CaO}$ & $\mathrm{Na}_{2} \mathrm{O}$ & $\mathrm{K}_{2} \mathrm{O}$ \\
\hline
\end{tabular}

\begin{tabular}{|c|c|c|c|c|c|c|c|c|c|c|}
\hline \multirow[b]{2}{*}{$\begin{array}{l}\text { Avg } \\
\text { Var } \\
\text { Sdt } \\
\text { Cva }\end{array}$} & \multicolumn{10}{|c|}{ South-Estonian area } \\
\hline & $\begin{array}{r}70.72 \\
2.89 \\
1.70 \\
0.02\end{array}$ & $\begin{array}{l}0.41 \\
0.04 \\
0.20 \\
0.49\end{array}$ & $\begin{array}{r}13.49 \\
0.67 \\
0.82 \\
0.06\end{array}$ & $\begin{array}{l}1.76 \\
1.22 \\
1.10 \\
0.63\end{array}$ & $\begin{array}{l}1.85 \\
0.35 \\
0.59 \\
0.32\end{array}$ & $\begin{array}{l}0.05 \\
0.00 \\
0.02 \\
0.42\end{array}$ & $\begin{array}{l}0.91 \\
0.12 \\
0.35 \\
0.38\end{array}$ & $\begin{array}{l}2.53 \\
0.51 \\
0.71 \\
0.28\end{array}$ & $\begin{array}{l}2.78 \\
0.03 \\
0.18 \\
0.06\end{array}$ & $\begin{array}{l}4.49 \\
0.49 \\
0.70 \\
0.16\end{array}$ \\
\hline & \multicolumn{10}{|c|}{ West-Estonian area } \\
\hline \multirow[t]{2}{*}{$\begin{array}{l}\text { Avg } \\
\text { Var } \\
\text { Sdt } \\
\text { Cva }\end{array}$} & $\begin{array}{r}70.16 \\
8.10 \\
2.85 \\
0.04\end{array}$ & $\begin{array}{l}0.38 \\
0.03 \\
0.17 \\
0.46\end{array}$ & $\begin{array}{r}13.86 \\
0.70 \\
0.84 \\
0.06\end{array}$ & $\begin{array}{l}1.63 \\
1.16 \\
1.08 \\
0.66\end{array}$ & $\begin{array}{l}1.66 \\
0.54 \\
0.73 \\
0.44\end{array}$ & $\begin{array}{l}0.05 \\
0.00 \\
0.02 \\
0.46\end{array}$ & $\begin{array}{l}0.79 \\
0.18 \\
0.43 \\
0.54\end{array}$ & $\begin{array}{l}2.75 \\
0.69 \\
0.83 \\
0.30\end{array}$ & $\begin{array}{l}3.38 \\
0.13 \\
0.36 \\
0.11\end{array}$ & $\begin{array}{l}4.42 \\
0.70 \\
0.84 \\
0.19\end{array}$ \\
\hline & \multicolumn{10}{|c|}{ Tallinn area } \\
\hline \multirow[t]{2}{*}{$\begin{array}{l}\text { Avg } \\
\text { Var } \\
\text { Std } \\
\text { Cva }\end{array}$} & $\begin{array}{r}73.43 \\
5.46 \\
2.34 \\
0.03\end{array}$ & $\begin{array}{l}0.21 \\
0.01 \\
0.08 \\
0.36\end{array}$ & $\begin{array}{r}12.83 \\
1.03 \\
1.01 \\
0.08\end{array}$ & $\begin{array}{l}0.97 \\
0.50 \\
0.70 \\
0.73\end{array}$ & $\begin{array}{l}1.33 \\
0.21 \\
0.45 \\
0.34\end{array}$ & $\begin{array}{l}0.03 \\
0.00 \\
0.01 \\
0.40\end{array}$ & $\begin{array}{l}0.71 \\
0.12 \\
0.35 \\
0.49\end{array}$ & $\begin{array}{l}2.14 \\
0.49 \\
0.70 \\
0.33\end{array}$ & $\begin{array}{l}3.06 \\
0.26 \\
0.51 \\
0.17\end{array}$ & $\begin{array}{l}4.40 \\
1.81 \\
1.31 \\
0.31\end{array}$ \\
\hline & \multicolumn{10}{|c|}{ Suursaari } \\
\hline$A v g$ & $\begin{array}{r}75.37 \\
7.30 \\
2.70 \\
0.04\end{array}$ & $\begin{array}{l}0.22 \\
0.02 \\
0.13 \\
0.59\end{array}$ & $\begin{array}{r}11.83 \\
1.22 \\
1.11 \\
0.09\end{array}$ & $\begin{array}{l}1.16 \\
0.28 \\
0.53 \\
0.46\end{array}$ & $\begin{array}{l}1.54 \\
0.45 \\
0.67 \\
0.43\end{array}$ & $\begin{array}{l}0.04 \\
0.00 \\
0.02 \\
0.55\end{array}$ & $\begin{array}{l}0.53 \\
0.14 \\
0.37 \\
0.70\end{array}$ & $\begin{array}{l}1.89 \\
0.13 \\
0.37 \\
0.19\end{array}$ & $\begin{array}{l}3.46 \\
0.26 \\
0.51 \\
0.15\end{array}$ & $\begin{array}{l}2.65 \\
1.08 \\
1.04 \\
0.39\end{array}$ \\
\hline
\end{tabular}

Table 4

Classification of Q-Fsp gneisses of the Tallinn area based on cluster analysis using the Niggli main values as input data and Euclidean distances for calculating the distance matrix. The averages for the Niggli main values for classes $\mathbf{I} a, \mathbf{I} b, \mathbf{I} c$, and II are provided

\begin{tabular}{l|l|l|l|l}
\hline \multirow{2}{*}{ Parameter } & \multicolumn{1}{|c}{$|c|$} & II \\
\cline { 2 - 5 } & $a$ & $b$ & $c$ & I \\
\hline
\end{tabular}

\begin{tabular}{llllr} 
al & 41.5 & 40 & 44 & 42.3 \\
$f m$ & 15 & 17.6 & 12.7 & 9.5 \\
$c$ & 12 & 12.7 & 9.3 & 9.8 \\
alk & 36.5 & 29.3 & 34.6 & 38.3 \\
si & 394 & 366 & 448 & 473 \\
\hline$c / f m$ & & & & \\
$c / a l k$ & 0.8 & 0.72 & 0.73 & 1.03 \\
$\mathrm{fm} / \mathrm{al}$ & 0.8 & 0.43 & 0.3 & 0.2 \\
& 0.36 & 0.44 & 0.28 & 0.22
\end{tabular}



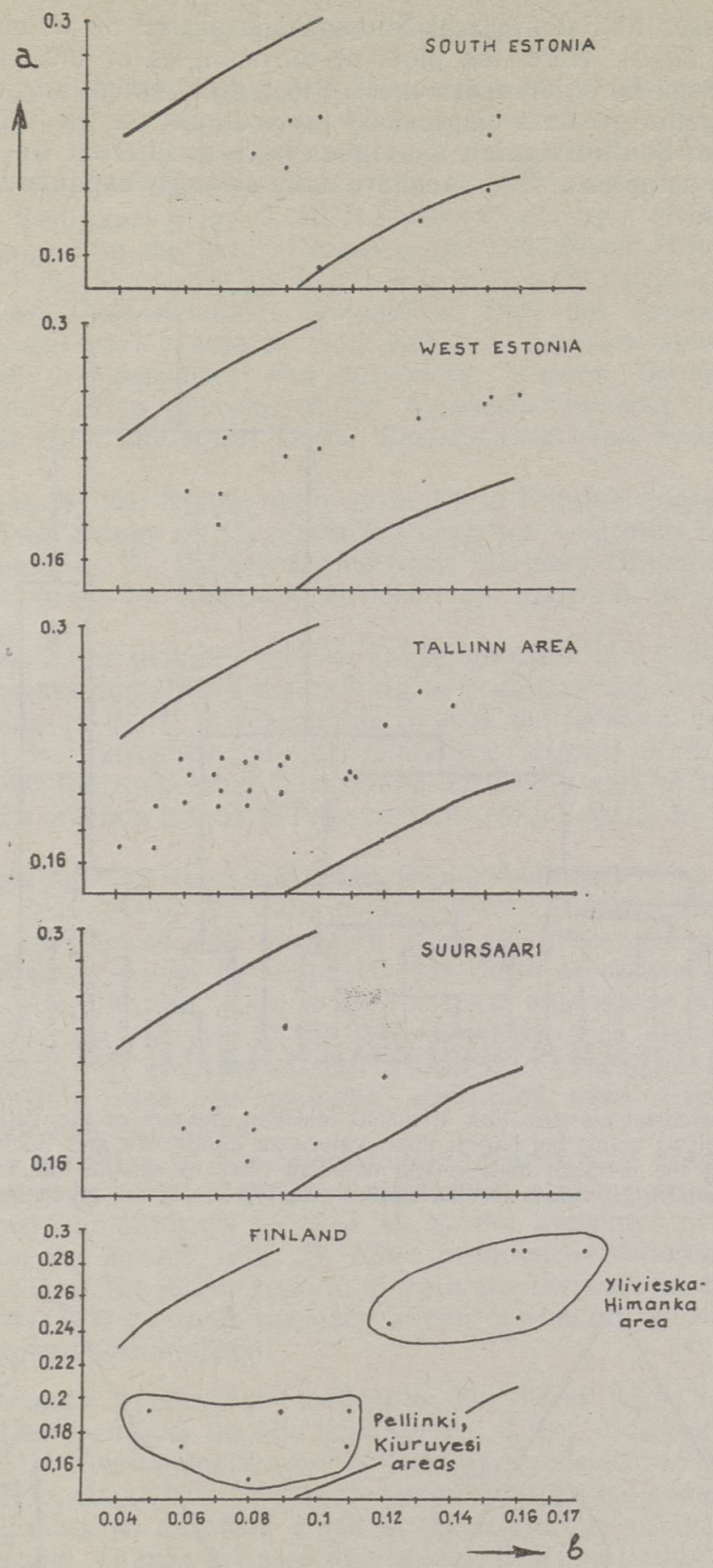

Fig. 3 Analyses of quartz-feldspar gneisses (leptites) from Estonian basement, Suursaari, and Finland plotted on Neelov's petrochemical diagram $(a-b) ; a=\mathrm{Al}_{2} \mathrm{O}_{3} / \mathrm{SiO}_{2}$; $b=\mathrm{Fe}_{2} \mathrm{O}_{3}+\mathrm{FeO}+\mathrm{MnO}+\mathrm{MgO}+\mathrm{CaO}$. The solid line marks the boundary between sedimentary (below) and volcanic + sedimentary rocks. The field between the two solid lines is a field where the parameters of volcanic and sedimentary rocks overlap. Chemical analyses are compiled using the collection of the Geological Survey of Estonia, Institute of Geology, Estonian Academy of Sciences, and works by Laitala (1973) and Marttila (1976). 
Q-Fsp gneisses of Estonia and Suursaari is shown on a triangular diagram (Fig. $5 a, b$ ). Here, the plots of the samples of the Tallinn, Suursaari, and West-Estonian areas overlap to a great extent and are stretched (i. e. having the greatest dispersion) towards almost the same direction. However, the South-Estonian analogues have a different $\mathrm{Ca}$ and alkaline specter. The samples of Suursaari are more strongly expanded out towards the $\mathrm{Na}$ axis.

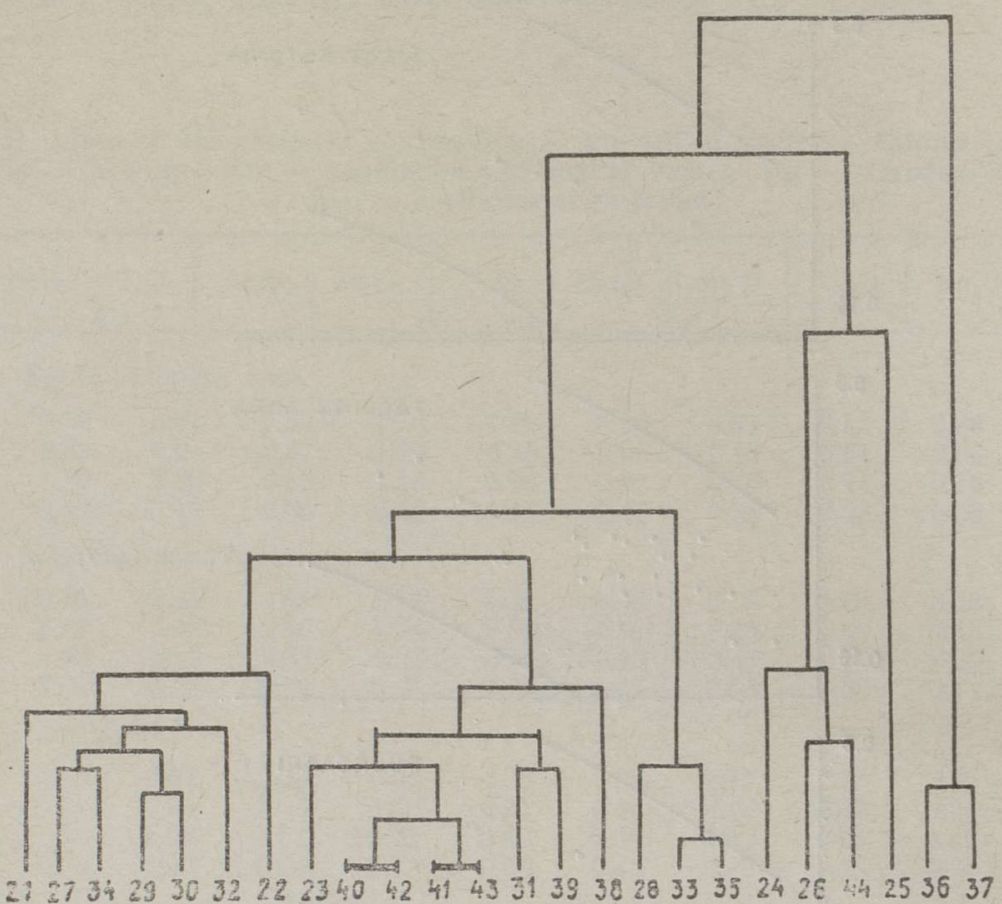

Fig. 4. A hierarchical classification of quartz-feldspar gneisses of the Tallinn area based on cluster analysis using the Niggli main values as input data and Euclidean distances for calculating the distance matrix. The numbers refer to sample numbers in Table 2 . The mean Niggli values for the classes (I $a, \mathrm{I} b, \mathrm{I} c$; II) are given in Table 4.
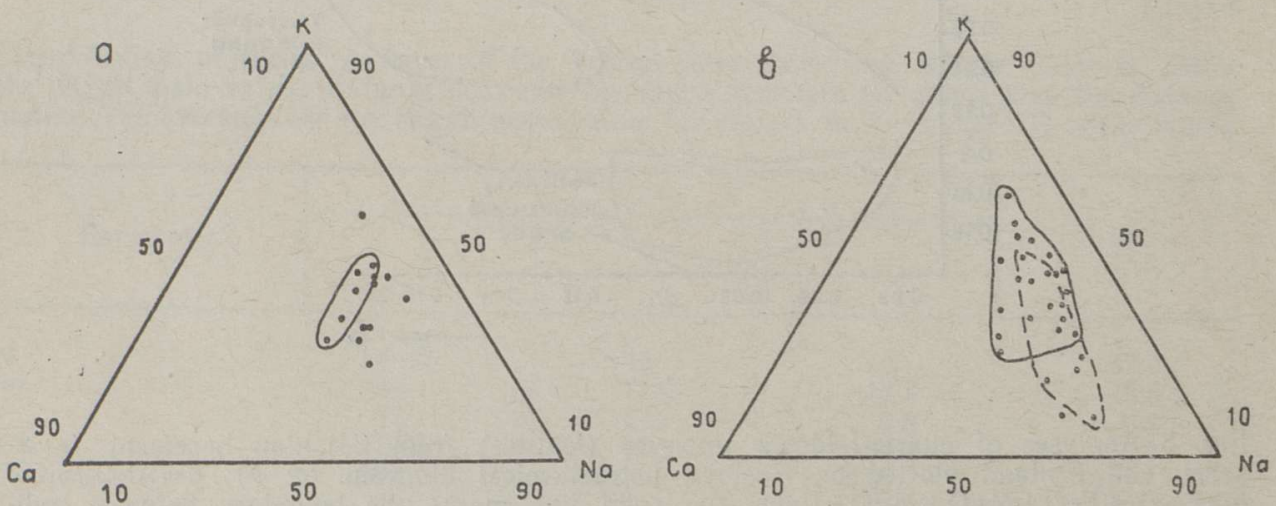

Fig. 5. $\mathrm{Na}, \mathrm{K}$, and $\mathrm{Ca}$ content of quartz-feldspar gneisses of Estonia and Suursaari. $a-$ South- and West-Estonian areas. The solid line surrounds the Q-Fsp gneisses of the South-Estonian area. $b$ - Tallinn area and Suursaari. The solid line surrounds the Q-Fsp gneisses of the Tallinn area; the dashed line surrounds the rocks of Suursaari. 


\section{Discussion and conclusions}

Relying upon the data given in literature we can compare Pellinki, Ylivieska, Alavieska, and Kiuruvesi, Finland, areas with the Estonian and Suursaari areas. On the basis of chemical composition, Q-Fsp gneisses and schists of the Pellinki area are similar to their analogues of the Tallinn area and Suursaari (Figs. 2, 3). On Neelov's diagram (Неелов, 1980) these rocks remain on the field of arkoses and subarkoses (Fig. 3). Marttila (1976) relates leptites of the Kiuruvesi area with volcanic rocks and their tuffes. By their chemical composition they are similar to Q-Fsp gneisses of Suursaari (Table 2). On Neelov's diagram these samples cover the field of subarkoses and polymictic arkoses. By the chemical composition the Q-Fsp gneisses of the Alavieska-Himanka area can be compared with their analogues in the West-Estonian and South-Estonian areas.

On the basis of the Niggli main value these Finnish analyses can be divided into two groups on the variation diagram - groups of high and low Si content (Fig. 2). Differences between Ylivieska-Himanka, Pellinki, and Kiuruvesi areas on Neelov's petrochemical diagram $(a-b)$ are displayed in Fig. 3.

Differences of the primary rock of Q-Fsp gneisses and later local and regional processes complicate the solving of problems connected with the genesis of those rocks. It is reasonable to look for identical traits in the dynamics of the petrochemical characteristics (Niggli main value) of rocks. Possibly, the rocks from the Kohila drill core can be taken as an example of the alternation of Q-Fsp gneisses with regard to basic magmatites.

Using these criteria, the similarities in the dynamics of $a l$, alk, and $c$ of the Q-Fsp gneisses of the Tallinn and West-Estonian areas become evident. The lengths of the variation diagram lines are also almost identical. Therefore, it can be supposed that these areas are geologically similar. It is possible that basic rocks (or their analogues) of magmatic origin that are characteristic of the West-Estonian area are likewise the basis for some Q-Fsp gneisses of the Tallinn area. The geological evolution of the Tallinn area has probably continued even after the WestEstonian block had stabilized.

The Q-Fsp gneisses of the South-Estonian area and Suursaari have certain differences from the above-mentioned areas according to the results of chemical analyses as well as by the dynamics of the Niggli main value on the si-axis (Fig. 2). More pronounced differences appear in the dynamics of the characteristic $c$ : with the increase in the value of $s i$, the characteristic $c$ either increases having a straight correlation with si or linear correlation is absent.

Acknowledgements. I thank my colleague Dr. Vello Klein for his constructive critical remarks on the manuscript. I am indebted to several geologists of the Geological Survey of Estonia, especially to Mr. M. Niin and Mr. H. Koppelmaa, for giving me permission to use some geological material and chemical analyses made in the laboratory of the Geological Survey of Estonia. Thanks are also due to Mrs. P. Runtal and Mr. I. Puura for their help in translating the manuscript into English.

\section{REFERENCES}

Laitala, M. 1973. On the Precambrian bedrock and its structure in the Pellinge region, South Finland. - Geol. Surv. Finland. Bull. 264, 8-14.

Martila, E. 1976. Evolution of the Precambrian volcanic complex in the Kiuruvesi area, Finland, - Geol. Surv. Finland. Bull. 283, 25-31. 
Salli, I. 1964. The structure and stratigraphy of the Ylivieska-Himanka Schist area, Finland. - Bull. Comm. geol. Finlande 211, 11-46.

Геологическая карта кристаллического фундамента республик Советской Прибалтики. 1980. Compiled by Пуура В. А., Апирубите Р. А., Биркис А. П., Гайлюс Р., Мотуза Г. Б., Озолинь Н. К.

Łфремова С. В., Стафеев K. Г. 1985. Петрохимические методы исследования горных пород. Москва: Недра, 53-57.

Кристаллический фундамент Эстонии. 1983. Москва: Наука.

Неелов А. Н. 1980. Петрохимическая классификация метаморфизованных осадочных и вулканических пород. Ленинград: Наука.

Никольский А. П., Наумов В. П. 1977. Осницкий геологический комплекс и время его формирования на территории Восточно-Европейской платформы. - Геол. журн., $37,3,110-118$.

Скобелев В. М. 1987. Петрохимия и геохронология докембрийских образований СевероЗападного района Украинского щита. Қиев: Наукова думка.

Чернов В. М. 1964. Стратиграфия и условия осадконаконления вулканогенных (лептитовых) железисто-кремнистых формаций Карелии. Москва; Ленинград: Наука, $30-35$.

Четвериков С. Д. 1956. Руководство к петрохимическим пересчетам. Москва: Государственное научно-техническое издательство литературы по геологии и охране недр, 64-83.

Щербак Н. П., Елисеева Г. Д., Левковская Н. Ю. 1978. Геологический и радиологиче ский возраст пород клесовской серии и осницкого комплекса. - Геол. журн., $38,4,28-43$.

Presented by V. Puura

Received

April 23, 1991

\section{Alvar SOESOO}

\section{EESTI JA SUURSAARE EELKAMBRIUMI KVARTS-PÄEVAKIVI GNEISSIDE (LEPTIITIDE) PETROKEEMIAST}

On analüüsitud Lõuna-Eesti, Lääne-Eesti ja Tallinna vööndi kvarts-päevakivi (Q-Fsp) gneisse 24 aluskorra puursüdamikust ning 9 paljandist Suursaarelt (kokku 53 proovi).

Eesti aluskorra ja Suursaare (Hoglandi) Q-Fsp gneisid (leptiidid) on peeneteralised, värvuselt hallikaspunased kivimid. Põhilisteks mineraalideks neis on kvarts, plagioklass, kaaliumpäevakivi ja biotiit, teisejärgulisteks küünekivi, muskoviit, epidoot, apatiit, maakmineraalid, granaat ja ortiit. Suurema kvartsi ja plagioklassi ning väiksema kaaliumpäevakivi ja biotiidi sisalduse poolest eristuvad Suursaare Q-Fsp gneisid. Vöönditevahelised erinevused ilmnevad ka kivimite keemilises koostises. Köigile Eesti Q-Fsp gneissidele on iseloomulik kõrge kaaliumisisaldus. Niggli põhiarvude baasil koostatud variatsioonireas ilmneb Tallinna ja Lääne-Eesti vööndi sarnasus arvude $a l, f m, c$ ja alk dünaamikas. Tallinna vööndi $Q$-Fsp gneisside klassifitseerimiseks keemilise koostise järgi on kasutatud ka klasteranalüüsi. Körvutades Eesti ja Suursaare Q-Fsp gneisside keemilist- koostist vastavate Soome analoogidega, võib märgata Pellinge ja Kiuruvesi vööndi kivimite mõningast sarnasust Suursaare ja osaliselt ka Tallinna vööndi Q-Fsp gneissidega.

\section{Aлвар COECOO}

\section{О ПЕТРОХИМИИ КВАРЦ-ПОЛЕВОШПАТОВЫХ ГНЕИСОВ (ЛЕПТИТОВ) ДОКЕМБРИЯ ЭСТОНИИ И О-ВА ГОГЛАНД}

Проведен анализ 53 проб кварц-полевошпатовых (Q-Fsp) гнейсов из 24 скважин Южно-Эстонской, Западно-Эстонской и Таллиннской зон и 9 обнажений о-ва Гогланд. Q-Fsp гнейсы фундамента Эстонии и о-ва Гогланд представляют собой красноватосерые однородные мелкозернистые породы. Породообразующими минералами являются кварц, плагиоклаз, калиевый полевой шпат и биотит. В меныших количествах присутствуют роговая обманка, мусковит, эпидот, апатит, гранат, ортит и рудные минералы. Установлено, что в Q-Fsp гнейсах о-ва Гогланд содержание кварца и плагиоклаза несколько ниже, а содержание биотита и калиевого полевого шпата несколько выше, чем в аналогичных породах других зон. Рассматриваемые гнейсы разных зон имеют определенные различия и в химическом составе. На основе чисел Ниггли построены диаграммы вариации, при помощи которых установлено сходство динамики главных петрохимических параметров $(a l, f m, c, a l k)$ Q-Fsp гнейсов Таллиннской и ЗападноЭстонской зон. Фигуративные точки проб вышеназванных зон совпадают довольно хорошо и на диаграмме Неелова $(a-b)$. Для классификации Q-Fsp гнейсов Таллиннской зоны на основе химического состава использована методика кластерного анализа. Сопоставлением установлено некоторое петрохимическое сходство Q-Fsp гнейсов o-ва Гогланд и Таллиннской зоны с аналогичными гнейсами из двух районов Финляндии - Киурувеси и Пеллинге. 